Mystetska osvita: tradytsii i novatsii - Proceedings of the International Scientific Conference An art education: traditions and innovations. (pp. 146-148). Melitopol. [in Ukrainian].

12. Chernyak, Ye. B. \& Yorkina, N. V. (2016). Formuvannia hendernoi kompetentnosti studentiv $\mathrm{u}$ protsesi yikh pidhotovky do umov vykonavskoi diialnosti [Methodical aspects of the formation of professional-performing competences of musicians with different individual and psychological peculiarities]. Pedagogical Education: Theory and Practice. Collection of scientific works. KamenetzPodolsk National University named after Ivan Ogienko. Kamenetz-Podolsk, 20(1-2016). pp. 163 - 168. [in Ukrainian].

13. Cherniak, Ye. \& Karetska, A. (2019). Metodychni aspekty formuvannia profesiino vazhlyvykh vykonavskykh yakostei uchniv shkil estetychnoho spriamuvannia [Methodical aspects of formation of professionally important performing qualities of pupils of schools of aesthetic orientation.]. Youth and market. Monthly scientific-pedagogical journal. Drogobych, Vol.5(172), pp. 73-79. [in Ukrainian].

14. Chernyak, Ye. B. \& Yorkina, N. V. (2018). Metodychni aspekty formuvannia profesiinovykonavskykh kompetentsii muzykantiv z riznymy indyvidualno-psykholohichnymy osoblyvostiamy [Formation of gender competence of students in the process of their preparation to the conditions of performance]. Alfred Nobel University Bulletin. Series: Pedagogy and Psychology. Dnepr, 2(16). pp. 102 - 109. [in Ukrainian].

15. Chernyak, Ye. \& Byletskya, M. et al. (2019). Transformation of sound cipher complexes in the history of musical art and their specific manifestations in the work of composers of the XVII-XXI centuries. Journal of History Culture and Art Research. Karabuk University. pp. 301-309. [in English].

Стаття надійшла до редакції 12.02.2021

УДК 78.421;78.27

DOI:

Марія Герега, кандидат мистецтвознавства, професор, завідувач кафедри загального та спеціалізованого фортепіано Львівської національної музичної академії імені М. В. Лисенка, Заслужений діяч мистецттв Украӥни

\title{
ФОРТЕПІАННІ СОНАТИ № 1 I 2 ВАСИЛЯ БЕЗКОРОВАЙНОГО З ПОЗИЩЙ ТОНАЛЬНИХ І ФОРМОТВОРЧИХ ОСОБЛИВОСТЕЙ
}

У статті здійснено спробу виявити тональні та формотвірні особливості сонат Василя Безкоровайного та і їх дидактичний потенціал. Констатовано, щзо сонатні жанри в доробку композитора $\epsilon$ художньо і дидактично вартісними зразками начіонального педагогічного репертуару. На їх прикладі можливе зіставлення класичної сонатної ииклічної структури з численними індивідуально-трактованими модифікачіями і рисами фольклорних та побутових жанрів начіонального музичного мистечтва. Матеріал сонат з огляду на виконавські завдання (звукотворчі, стильові, жанрові, фактурні) иікавим є прикладом украйнського дидактичного репертуару сміливого трактування форми і тонального плану, становить добре підгрунтя для розвитку тонально-гармонічного мислення, ритмічних труднощів, пластичного мелодичного голосоведення інтервальними смугами, діалогічних перекличок далеких регістрів, різних типів акордової техніки.

Ключові слова: фортепіанне мистецтво композитори діаспори; дидактичний репертуар; формотворчі особливості; виконавські завдання.

Jim. 7.

Maria Gerega, Ph.D.(Art History), Professor, Head of the General and Specialized Piano Department Lviv Mykhaylo Lysenko National Music Academy, Honored Art Worker of Ukraine

\section{PIANO SONATAS No 1 AND 2 BY VASYL BEZKOROVAINY FROM THE POSITIONS OF TONALAND FORMATIVE FEATURES}

The article attempts to identify the tonal and formative features of Vasyl Bezkorovainy's sonatas and their didactic potential. Throughout his life, he consistently created a didactic repertoire, which was characterized by a clear understanding of pedagogical tasks and a bright national musical vocabulary, sought in each period of his work to make quality editions of these works. The sonatas were written for didactic purposes, and therefore fundamentally meet the criteria of educational compositions. They were created by an artist who had significant pedagogical experience of teaching in Ukrainian professional educational institutions of Ternopil and Zolochiv (in 


\section{ФОРТЕПІАННІ СОНАТИ № 1 I 2 ВАСИЛЯ БЕЗКОРОВАЙНОГО ЗПОЗИЦЙ ТОНАЛЬНИХ І ФОРМОТВОРЧИХ ОСОБЛИВОСТЕЙ}

the branches of the Higher Music Institute named after M. Lysenko) and successfully continued this activity in exile. It is stated that sonata genres in the work of the composer are artistically and didactically valuable examples of the national pedagogical repertoire. On their example it is possible to compare the classical sonata cyclic structure with numerous individually interpreted modifications and features of folklore and household genres of national musical art. The material of sonatas is an interesting example of the Ukrainian didactic repertoire in view of performance tasks (sound, style, genre, texture), but also serves as an example of bold interpretation of form and tonal plan. It serves as a good basis for the development of tonal-harmonic thinking, rhythmic difficulties, plastic melodic voting in interval bands, dialogic reverberations of distant registers, and various types of chord technique.

Keywords: piano art; diaspora composers; didactic repertoire; formative features; performance tasks.

П остановка проблеми. Ім’я Василя Безкоровайного належить до великого переліку митців діаспори, які на десятиліття вимушено випали 3 традиції виконання, з концертної практики, а отже - стали незнаними для прийдешніх поколінь українців. Вони творчою діяльністю зробили чимало для української музичної культури в своєму краю і в діаспорі, здобувши визнання не лише співвітчизників, але й фахівців інших держав та націй. Проте мусимо бути свідомими, що в зарубіжжі відходять покоління тих, хто був свідками їх злетів і розквіту, їх нащадки асимільовані в інших культурних реаліях, а нам, українцям і Україні живущим, належить встигнути зафіксувати і зберегти спогади рідних та близьких, опрацювати родинні архіви, видання, звукозаписи, і здійснити найскладніше - повернути ці імена на концертні естради, у програми виконавців, у фахові підручники і просвітницькі програми - а отже, зберегти їх від забуття для нашої культури.

В. Безкоровайний - хормейстер, композитор, концертмейстер, музикант-поліінструменталіст, педагог і творець дидактичного музичного репертуару, організатор музичного і театрального життя українців міжвоєнного періоду у Тернополі, Золочеві, Львові, а в після війни в еміграції - в Габльонці, Гогенемсі, Баффало (де він очолював філію Українського музичного інституту Америки ( УМІА). Протягом усього життя він послідовно творив дидактичний репертуар, який вирізнявся чітким усвідомленням педагогічних завдань і яскраво національним музичним словником. I, що особливо цінно, намагався в кожен період своєї творчості здійснити якісні видання цих творів. Понад півстоліття ім'я автора більше 350 різножанрових творів, що виконувалися в Австралії, Канаді, США, а до початку 1940-х і в Україні, залишались маловідомими на рідній землі.

Творчість митця почала повертатися на батьківщину лише в роки перед здобуттям Незалежності. У 1992 р. Н. БезкоровайнаСтецьків передала твори і значну частину архіву до Тернопільського краєзнавчого музею. Завдяки ініціативі Сімферопольського Науково-творчого товариства Василя Безкоровайного та нащадків композитора (внучатого племінника, заслуженого працівника культури України Богдана Безкоровайного та концертно-оперної співачки, заслуженої артистки України, доцента Кримського університету культури, мистецтв і туризму Наталії Безкоровайної 2004 р. в Україні вийшов нотний збірник "Українські думки” для скрипки i фортепіано (Сімферополь, 2004), “Сонати для фортепіано” (Сімферополь, 2008) та низка інших репертуарних і дидактичних видань.

Аналіз основних досліджень і публікацій. На відміну від якісних нотних видань, дослідження творчого шляху і аналіз доробку митця іще залишається справою майбутнього. Більшість публікацій, присвячених цій тематиці, $\epsilon$ популярними чи мемуарними, орієнтовними на ознайомлення з постаттю через пресу загального профілю (як, наприклад, статті О. Бризун-Соколик [2; 3]). Окремі статистичні дані можна почерпнути зі словниково-довідникових статей П. Медведика [5], О. Шевчука [7], І. Дуди [4]. Найбільш концепційними з музикознавчої точки зору залишаються проблемні розвідки І. Новосядлої [6] та Н. Безкоровайної [1], присвячені постановці проблеми огляду творчості у найбільш загальних рисах. Натомість аналіз жанрової специфіки, виразових засобів, формотвірних засад, оцінка дидактичних цінностей педагогічної літератури заторкуються лише у передмовах до нотних видань.

Мета статті - виявити тональні та формотвірні особливості сонат Василя Безкорованого та і їх дидактичний потенціал.

Виклад основного матеріалу. Композиції у формі сонатного циклу є невід'ємною складовою фахової підготовки виконавця на фортепіано. Порівняно $з$ п’єсами чи етюдами, цей жанр ставить вимоги усвідомлення масштабного розгортання драматургії цілого, відмінностей експозиційності і розробковості викладу, різних підходів до образного, фактурного, регістрового, жанрового переосмислення тематизму. До цього додаються i стильові особливості, які зумовлюють трактування структурного i мелодичного начал, тонально-гармонічного мислення, типологічних i особисто- 
індивідуалізованих ознак. У сучасному педагогічному процесі поряд із сонатами i сонатинами Ф. Кулау, Д. Скарлатті, М. Клементі, Й. Гайдна, Л. ван Бетовена, дедалі активніше опановуються композиції митців Свропи широкого національного та стильового спектру (Р. Шумана, Ф. Шуберта, Й. Брамса, М. Метнера, М. Равеля, Ф. Пуленка, Б. Бартока, та ін.). Не менш важливим $\epsilon$ все зростаючий інтерес до взірців жанру національної фортепіанної сонати, що зумовлено дослідженням та публікацією все нових маловідомих чи забутих творів композиторів міжвоєнного періоду і найновітніших композицій митців сучасності.

Серед опусів першої половини ХХ ст., безсумнівно, привабливим комплексом художньої вартості, національного характеру та наявністю цінностей дидактичних характеристик вирізняються “Фантастична соната” № 1 ор. 44 Ф. Якименка (1910), Соната Cis-dur В. Барвінського (1910), Сонатне алегро для фортепіано (ор. 1) Л. Ревуцького (1914), п’ять сонат М. Рославця (1914-1923), три сонати В. Косенка, 6 сонат В. П. Задерацького (з них Сонати для фортепіано № 1 і 2 - одночастинні), одночастинна Соната ор. 4 В. Грудина (1924), 3 сонати (1924-1925) Б. Кудрика, Соната-балада Б. Лятошинського ор. 19 № 2 (1925), Соната для фортепіано 3. Лиська (1927), Соната А. Рудницького (1931), Сонатина для фортепіано в чотири руки Василя Витвицького (у двох частинах). Кожна з них $є$ цікавим прикладом на дотримання стильових особливостей (неокласицизму, неоромантизму, неофольклоризму, модерну), серед творів наявні одно-, двочастинні композиції, класичні інетипові тричастинні структури 3 контрастом гомофонних і поліфонічних форм.

Музична діячка канадської української діаспори Оксана Бризгун-Соколик у телефонній розмові для радіопрограми "Українська музика на Заході" згадувала: "Моє знайомство 3 композитором Василем Безкоровайним почалося у 1959 р. Йому тоді було 79 років. Він був тоді старший пан і він був дуже активний, і в композиції, і в навчанні, і в диригуванні і т.д. Я вчила гри на фортепіано в Торонто. Ми мали масу нот до диспозиції канадських видань, але не було взагалі нічого українського. I одного дня я побачила в “Свободі" оголошення, що можна дістати українські твори від Василя Безкоровайного 3 Баффало. Я одразу написала листа і з того часу розпочалося наше знайомство. Діти його твори дуже полюбили, тому, що це були симпатично скомпоновані твори, базовані в багатьох випадках на українських народних піснях, i їм це було i знайоме і рідне" $[3,3]$.
Необхідність і високу запотребованість творів та видань такого роду підтверджує Ірина Новосядла, анонсуючи видання двотомника фортепіанних творів композитора: “Свою активну педагогічну діяльність В. Безкоровайний продовжив в США, очоливши філію УМІА в Баффало. В архівних документах композитора, переданих в Україну його донькою, зустрічаються листи, в яких вчителі українських музичних шкіл в еміграції “просять Поважного Професора музики скомпонувати твори для дитячого репертуару" ... Тож, концертуючи і даючи уроки гри на фортепіано, композитор створював нові фортепіанні опуси" $[6,68]$. Важливо, що низка 3 названих творів були створені 3 дидактичною метою, а отже, засадничо відповідають критеріям навчальних композицій. Саме до таких належать сонати Василя Безкоровайного, створені митцем, що мав значний педагогічний досвід викладання в українських фахових навчальних закладах освіти Тернополя і Золочева (у філіях Вищого музичного інституту ім. М. Лисенка) і з успіхом продовжив цю діяльність в еміграціі.

Соната № 1 Василя Безкоровайного є тричастинним циклом 3 відносно традиційною будовою (1 ч. Сонатне Allegro; 2 ч. Adagio cantabile; 3 ч. Finale. Tempo di Kolomyjka). Проте жанрово, композиційно, з точки зору тональногармонічного і тематичного розвитку вона становить значний інтерес.

Перша частина експонує основну тональність (c-moll) і провідну лірико-психологічну стильову концепцію твору. Стилістику відрізняє поєднання неоромантичних рис 3 яскравим національноінтонаційним началом, панування пісенноромансового типу мелодичних побудов. Всі форми $є$ вільнотрактованими, а репризні проведення тем - жанрово, інтонаційно і фактурно динамізованими, що ставить перед виконавцем завдання чіткого осмислення логіки цих змін у драматургії цілого. Сонатна форма починається розгорненим вступом, де поєднуються альбертієві баси і акордові вертикалі, в якому кристалізуються інтонації наступної головної партії. Її виклад наскрізь мелодизований, збагачений альтераціями і відхиленнями у субдомінантову сферу, має діалогічно-дуетне співвідношення голосів у крайніх регістрах.

Ще більш диференційованою постає ця дуетність у побічній партії у субдомінантовій тональності (f-moll), натомість альтерації поступаються місцем сміливим відхиленням та широкому регістровому розвитку. Кода, інтонаційно споріднена матеріалові вступу, завершується закріпленням автентичної каденції. 


\section{ФОРТЕПІАННІ СОНАТИ № 1 I 2 ВАСИЛЯ БЕЗКОРОВАЙНОГО ЗПОЗИЦЙ ТОНАЛЬНИХ ІФОРМОТВОРЧИХ ОСОБЛИВОСТЕЙ}

Розробка (вводиться зівставленням тональності C-dur) базується переважно на матеріалі побічної партії, що набуває світлого колориту й інтенсивного розвитку за рахунок розширення діапазону, терцових, октавних та акордових дублювань мелодичних поспівок, звертання до інтонацій партії вступу слугує зв'язкою-переходом до драматизованої експресивної репризи ущільненою фактурою та ускладнено ритмікою. Початковий ліричний образ повертається лише в заключному реченні частини.

Друга частина (Adagio cantabile) починається скорботно-статичною хорально-акордовою темою в низькому регістрі у формі квадратного періоду y d-moll, що викликає фактурні, образні та жанрові асоціації з жанром пасакалії. Ї̈̈ подальший розвиток позначений емоційною напругою, канонічно-імітаційними перекличками на тлі акордової пульсації альтерованих гармоній 3 короткочасним відхиленням у As-dur. Складністю $\epsilon$ відтворення стану стримуваної емоції (у межах динамічної градації $\boldsymbol{p}$ - $\boldsymbol{m} \boldsymbol{f}$ ) за умов насиченої акордової фактури i октавно-секстових мелодичних смуг.

Цікавим відтворенням регіональної інструментальної традиції є 3 частина (Finale. Tempo di Kolomyjka). Коломийку, як жанрову опору заключного розділу циклу зустрічаємо ще в гітарних композиціях М. Вербицького. Композитор тут звертається до рапсодичної, вільної контрастно-складової форми 3 рисами варіаційності, однак з чітким членуванням на квадратні побудови - на зразок танцювальних “колін” у гуртових формах інструментального музикування, де кожне нове тематичне утворення характеризується фактурним і жанровим контрастом (козачок, метелиця, мазур). Завершується частина потужним утвердженням основної тональності з пануванням заключного типу викладу.

О. Бризгун-Соколик у статті-спомині про композитора згадувала, що першу фортепіанну сонату, написану в 1960 р., було присвячено їй. Отже, наступні № 2 та 3 створено у пізній період понад 80-літнім митцем [2, 2-3].

Соната № 2, As-dur, $є$ твором, що з точки зору музичної форми відрізняється оригінальним композиторським вирішенням. Будова циклу загалом традиційна: 1 частина - вільно трактована сонатно-варіаційна форма, 2 частина - наскрізна, 3 частина - трип'ятичастинна (подвійна тричастинна) форма.

У першій частині Allegretto, виклад головної партії $є$ акордовим, він має тричастинну репризну форму з середнім розділом в якому вводиться нова тема з розробковим розвитком і відхиленням y Des-dur.

Як і середній розділ головної партії, побічна тема - лірично-пісенна. Вона проводиться в Desdur, а також зберігає в акомпанементі пульсуючі акордові фігури, притаманні середньому розділу головної партії, що надає їй рис елегії. Розвиток теми проходить через низку відхилень, одразу перетікаючи в невелику розробку на матеріалі побічної та головної партій.

Репризне проведення головної партії більш потужне (As-dur, a tempo, $\boldsymbol{f}$ ) октавою вище ніж у експозиції та монолітним октавним басом, однак скорочене. Натомість побічна партія, яка зберігає побічну тональність Des-dur (як і сонаті № 1 композитор використовує субдомінантове співвідношення), набуває широкого розвитку. В коді з'являється інтонаційно видозмінена тема середнього розділу головної партії, яка набуває характеру алюзії на "Весняну пісню" Ф. Мендельсона. Заключний розділ коди опирається на інтонації головної партії у основній тональності, що надає формі рис вільно трактованої рондо-сонати.

Друга частина Adagio (3/4, Es-dur, p) $є$ ідилічною пасторальною картиною природи. Про це свідчать імпровізаційні імітації сопілкових награшів у високому регістрі з підкреслено лаконічним супроводом та звуконаслідування пташиного щебету (численні різновиди форшлагів, трелі у третій октаві). Середній розділ містить варіантні канонічно-імітаційні переклички, що надають звучанню просторовості.

Фінал (Presto, 2/4, As-dur) опирається на танцювальну жанровість (близьку до козачка), $\mathrm{i}$ написаний у вільно трактованій трип'ятичастинній формі (АВАВА $) 3$ кодою на матеріалі рефрену.

Висновки та перспективи подальших досліджень. Сонатні жанри в доробкуВ. Безкоровайного $\epsilon$ цікавими зразками національного педагогічного репертуару. На прикладі його Сонати № 1 маємо змогу провести докладне порівняння класичної сонатної циклічної структури з численними індивідуально-трактованими модифікаціями і рисами фольклорних та побутових жанрів національного музичного мистецтва. Окрім цього, музичний матеріал сонати служить добрим підгрунтям для розвитку тонально-гармонічного мислення, ритмічних труднощів, пластичного мелодичного голосоведення інтервальними смугами, діалогічних перекличок далеких регістрів, різних типів акордової техніки. Друга фортепіанна соната Василя Безкоровайного $є$ не лише цікавим прикладом українського дидактичного репертуару з огляду на виконавські 
завдання (звукотворчі, стильові, жанрові, фактурні), але й слугує прикладом сміливого трактування форми і тонального плану. Подальші дослідження як педагогічних, так і концертних композицій митця не лише сприятимуть вияву тенденцій розвитку відповідних жанрів у творчості митців діаспори, послужать порівняльному аналізу зі шляхами еволюціонування в Україні, але й допоможуть відновити належне місце в національній виконавській та педагогічній традиції.

\section{ЛIТЕРАТУРА}

1. Безкоровайна Н. Творчість Василя Безкоровайного як об'єкт мистецтвознавчого дослідження. Київське музикознавство. Культурологія і мистецтвознавство : збірка статей. Київ: КІМ ім. Р.Глієра, 2011. Вип. 38. С. 287-298

2. Бризгун-Соколик О. Василь Безкоровайний. Свобода: український тижневик. Торонто, Канада. 1983. № 145. 3 серпня. С. 2-3.

3. Бризгун-Соколик О. Спомин про Василя Безкоровайного: у сорокову річницю смерті. Новий илях. Торонто, Канада. 2006. 9 березня. C. 3

4. Дуда I. Тернопільщина мистецька. Місто Тернопіль: (Композитор, диригент і музичний діяч В. Безкоровайний). Свобода. 1993. 9 лют.

5. Медведик П. Василь Безкоровайний композитор, диригент, піаніст-акомпаніатор, засновник музичних шкіл, хорів, оркестрів, диригент хору Тернопільського “Бояна”. Наук.краєзнавч. часопис Тернопілля. 1994. № 1. С. 212220.

6. Новосядла I. Грані таланту Василя Безкоровайного. Українська музика. 2017. № 4 (26) С. 62-70.

7. Шевчук О. Безкоровайний Василь Васильович. Украӥнська музична енциклопедія. Київ: Ін-т мистецтвознавства, фольклористики та етнології ім. М.Т. Рильського НАН України, 2006. T.1. C. $164-165$.

\section{REFERENCES}

1. Bezkorovaina, N. (2011). Tvorchist Vasylia Bezkorovainoho yak obiekt mystetstvoznavchoho doslidzhennia [Vasyl Bezkorovainy's work as an object of art criticism]. Kyiv musicology. Culturology and art history: a collection of articles. Kyiv. Vol. 38. pp. 287-298. [in Ukrainian].

2. Bryzghun-Sokolyk, O.(1983). Vasyl Bezkorovainyi [Vasyl Bezkorovainy]. Svoboda: Ukrainian Toronto, Kanada. No. 145. pp. 2-3. [in Ukrainian].

3. Bryzghun-Sokolyk, O. (2006). Spomyn pro Vasylia Bezkorovainoho: u sorokovu richnytsiu smerti [Memory of Vasyl Bezkorovainy: on the fortieth anniversary of his death]. A new way.Toronto, Kanada. p. 3. [in Ukrainian].

4. Duda, I. (1993). Ternopilshchyna mystetska. Misto Ternopil: (Kompozytor, dyryhent i muzychnyi diiach V. Bezkorovainyi) [Ternopil region is artistic. City of Ternopil: (Composer, conductor and musician V. Bezkorovainy)]. Svoboda. [in Ukrainian].

5. Medvedyk, P. (1994). Vasyl Bezkorovainyikompozytor, dyryhent, pianist-akompaniator, zasnovnyk muzychnykh shkil, khoriv, orkestriv, dyryhent khoru Ternopilskoho "Boiana [Vasyl Bezkorovainy - composer, conductor, pianistaccompanist, founder of music schools, choirs, orchestras, conductor of the choir of Ternopil "Boyan"]. The scientific and local lore journal of Ternopil. No. 1. pp. 212-220. [in Ukrainian].

6. Novosiadla, I. (2017). Hrani talantu Vasylia Bezkorovainoho [The facets of Vasyl Bezkorovainy's talent]. Ukrainian music. No. 4 (26) pp. 62-70. [in Ukrainian].

7. Shevchuk, O. (2006). Bezkorovainyi Vasyl Vasylovych [Bezkorovainy Vasyl Vasilyovych]. Ukrainian music encyclopedia. Kyiv, Vol.1. pp. 164-165. [in Ukrainian].

Стаття надійшла до редакції 22.02.2021

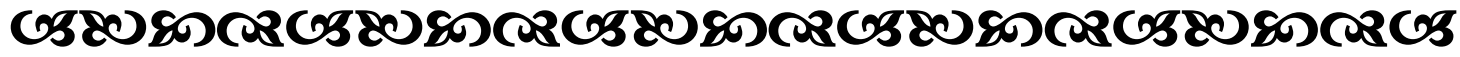

$$
\begin{array}{r}
\text { “Розқажи - i л забуду, поқажи - i я пізнаю, дай зробити самому - } i \text { я зрозумію”. } \\
\text { Китайське прислів'я }
\end{array}
$$

"Dивне мистеитво - музиқа - найпоетичніше $i$ найточніше з усіх мистеитв, розпливчасте, як сон і точне, якалгебра".

Ti de Monaccar бранцузький письменник

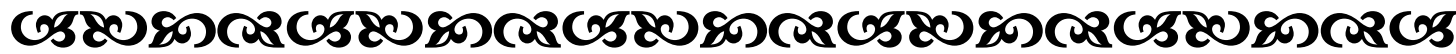

